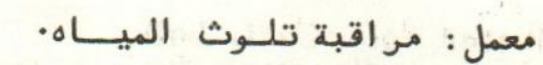

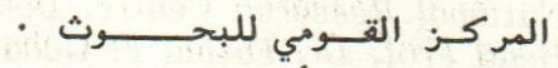
مدير المعمل : أ.د./ الماطمـ الجوهرى.

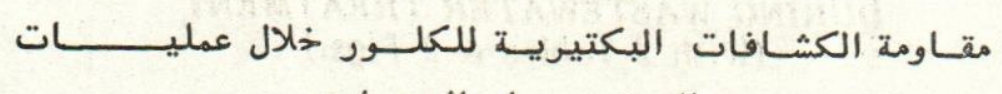

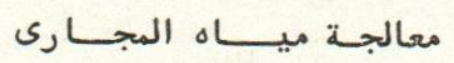

شـــوقي الهـوارى جـلال خلـف الله

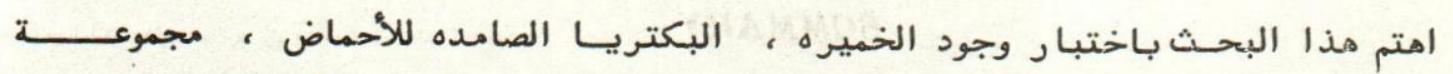

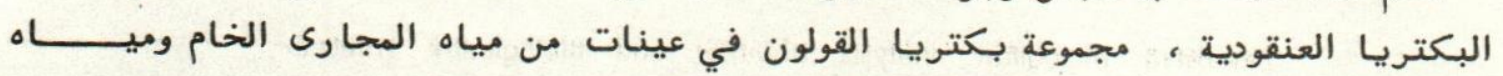

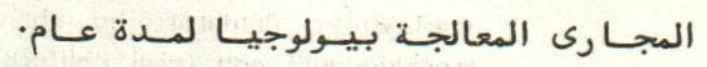

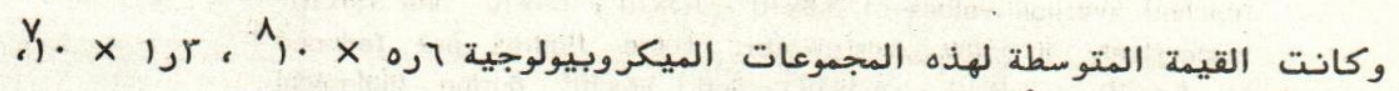

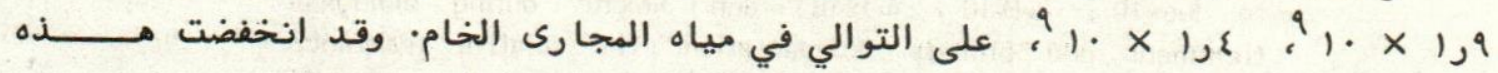

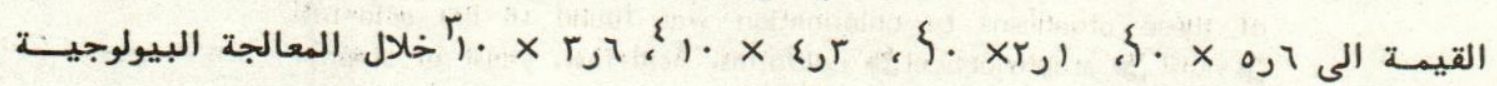

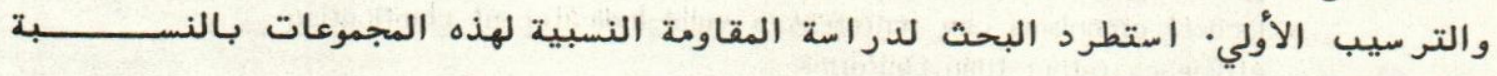

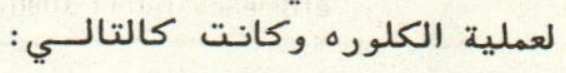

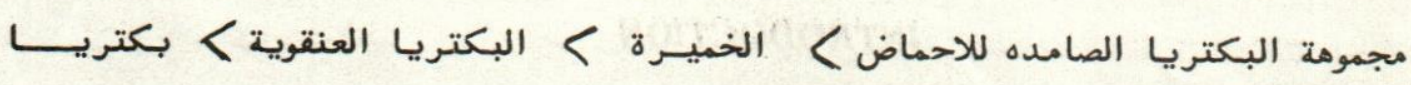
· القــولون

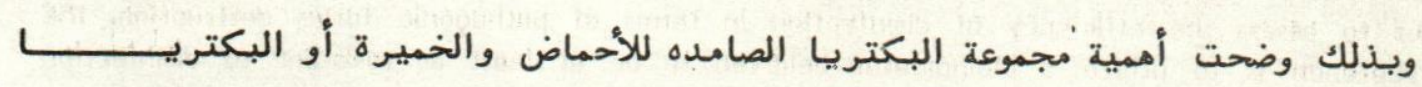

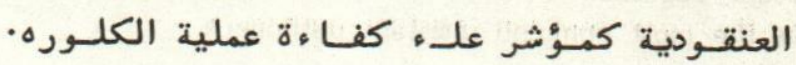


Water Poll. Cont. Lab.,

National Research Centre, Dokki, Cairo.

Head Prof. Dr. Fatma El Gohary.

\title{
RESISTANCE OF BIOINDICATORS TO CHLORINATION \\ DURING WASTEWATER TREATMENT
}

(With 2 Tables \& 2 Figs.)

By

S. EL-HAWAARY and G.M. KHALAFALLA *

(Received at $1 / 10 / 1986$ )

\begin{abstract}
SUMMARY
Extensive biological analysis of raw and biologically treated wastewater demonstrated the presence of yeasts, acid fast, staphylococci and total coliform grganisms in all tegsted samples reached average values of $5.6 \times 10^{8}, 1.3 \times 10^{7}, 1.9 \times 10^{9}$ and $1.4 \times 10^{9}$ respectively in raw $x_{4}$ wastewater. These figures are reduced to $5.6 \times 10^{4}, 2.1 \times 10^{4}, 4.3 \times 10^{4}$ and $3.6 \times 10^{3}$ during biological treatment and primary sedimantation. The relative resistance of these organisms to chlorination was found to be: acid-fast $>$ yeast $>$ staphylococci $>$ coliforms. Acid-fast, yeast or staphylococci organisms can represent a valid indicator of chlorination efficiency rather than coliforms.
\end{abstract}

\section{INTRODUCTION}

The major objective of any disinfectant application used for either wastewater effluent or water supplies is to produce a finished accepted product from a public health stand point. In order to assess the efficiency of disinfection in terms of pathogenic forms destruction, the usual approach is to utilize a bioindicator believed to be at least as resistant to disinfection as the most common resistant pathogens.

A bioindicator should be rapidly and certainly quantifiable in water and wastewater samples by simple and easily applied techniques (BOND, 1966). Total and faecal coliform organisms, are currently the most commonly used groups of bioindicators, but they do not meet the criterion of being as resistant to chlorine disinfection as the most resistant pathogens. So, the suitability of coliforms for evaluating chlorine disinfection efficiency may be seriously questioned (RUDOLPH, et al. 1950; GALLAGHER \& SPINO, 1968 and GELDREICH, et al. 1968). This is particularly true where wastewater re-use are considered, in such situation, protection of the public health is paramont. Generally the validity of using conventional indicator organisms to judge the effectiveness of reclamation processes has been questioned (MCFETERS, et al. 1974; BERG and METCALF, 1978 and GRABOW, et al. 1980).

This study was performed to evaluate the efficiency of yeasts, acid-fast staphylococci and total coliform bacteria as bioindicators for chlorine disinfection efficiency.

* Dept. of Microbiology, Fac. of Agric., Cairo Univ. 


\section{EL-HAWAARY and KHALAFALLA}

\section{MATERIAL and METHODS}

\section{Sampling:}

Samples were collected in sterile 1 litre, wide mouth glass bottles and tested within one hour of collection. In the case of chlorinated samples, $1 \mathrm{ml}$ of $0.05 \%$ sodium thiosulfate per litre of samples was aseptically added to each bottle, immediately after collection and mixed well.

A set of samples were collected and analyzed twice monthly from raw wastewater and biologically treated effluents of Rotating Biological Contactor (STENGEIN Anlagenban und Verfahrenstechnik, 7200 Tuttlingen, RBC).

\section{Chlorination Experiments}

\section{Patch chlorination experiments}

Six litres of biologically treated effluent settled for one hour were collected into a sterile 10 litres capacity bottle (ground glass stoppered). A $15 \mathrm{mg}$ chlorine per litre of the effluent was achieved by the addition of the suitable volume of sodium hypochlorite (Farmitalia Carloerba S.P.A. Milano, Italy), then the bottle was stoppered and the content were thorough mixed. Samples were aspirated and dechlorinated after different contact time intervals i.e. 15,30,60,90 and 120 minutes.

\section{Continuous flow chlorination experiments}

A contact baffled tank (99 × $61 \times 21 \mathrm{~cm}$ ), of 125 litres capacity was used. Different detention times were reached by changing the flow of influent as well as the chlorine feeding solution to the contactor by means of prestaltic dosing pump. Contact time periods were adjusted to be 30,60 or 120 minutes. Samples were collected from the outlet of the contactor and immediately dechlorinated. The system was adjusted and operated 24 hrs before sampling. Three samples were collected during each operation at the designed contact time.

\section{Microbiological Assay and Media}

To reach the suitable number of each parameter, three different ten fold dilution were prepared from each sample and used for the enumeration of each parameter.

\section{Enumeration of total bacterial counts}

Poured plate count technique according to APHA (1985) was carried out.

\section{Enumeration of total coliform organisms}

Membrane filter technique was employed according to APHA (1985) using M-endo agar and Sartorious Membrane filter.

\section{Enumeration of Acid-fast bacteria.}

Samples were treated by thorough mixing with equal volume of $2.5 \%$ oxalic acid for 10 minutes. The mixture was neutralized with $2 \% \mathrm{NaOH}$ using electronic $\mathrm{pH}$ meter (Knick Digital-pHMeter 646). After filtration, membranes were placed onto the enriched Dubos agar medium (Difco) and incubated at $37^{\circ} \mathrm{C}$ for approximately 7 days. Filters supporting growth were gently heat dried and stained by Brooks acid fast stain (ENGELBRECHT, et at. 1977). Pink to red colonies consisting of acid fast organisms were counted. 


\section{RESISTANCE OF BIOINDICATORS TO CHLORINATION}

\section{Enumeration of Staphylococci.}

Staphylococcus Medium No. 110 (Difco) was used as a selective medium. Total staphylococci as well as orange or pigmented pathogenic staphylococci were counted after 48 hours of incubation at $35^{\circ} \mathrm{C}$ (DIFCO manual, 1958).

\section{Enumeration fo yeasts.}

Littman oxgall agar (Difco) containing chloramphenicol $5 \mathrm{~g}$, pencillin 50,000 units and streptomycin $30 \mathrm{mg}$ per litre $(\mathrm{pH}$ 6.5) was used to support yeast growth. Membrane filters were incubated at $18-22^{\circ} \mathrm{C}$ for 48 hours, after which yeast colonies were counted.

\section{RESULTS}

The range and average counts of total viable bacteria at $22^{\circ} \mathrm{C}$ (TVC 22) and $37^{\circ} \mathrm{C}$ (TVC 37), total coliform M-F count (TC), Acid-fast organisms ( $A-F$ ), yeasts and staphylococci (Staph.) during one year in raw and settled wastewater are presented in table 1 . The densities of the selected indicator, total staphylococci (T.Staph.), coloured or pathogenic staphylococci (C.Staph.) and TVC 22 and TVC 37 were fairly consistent in raw wastewater.

Acid-fast bacilli were relatively present in low numbers than the other indicators especially in raw and settled sewage samples.

Table (1)

The average density $/ 100 \mathrm{ml}$ of biological parameters in raw and the one hour settled sewage

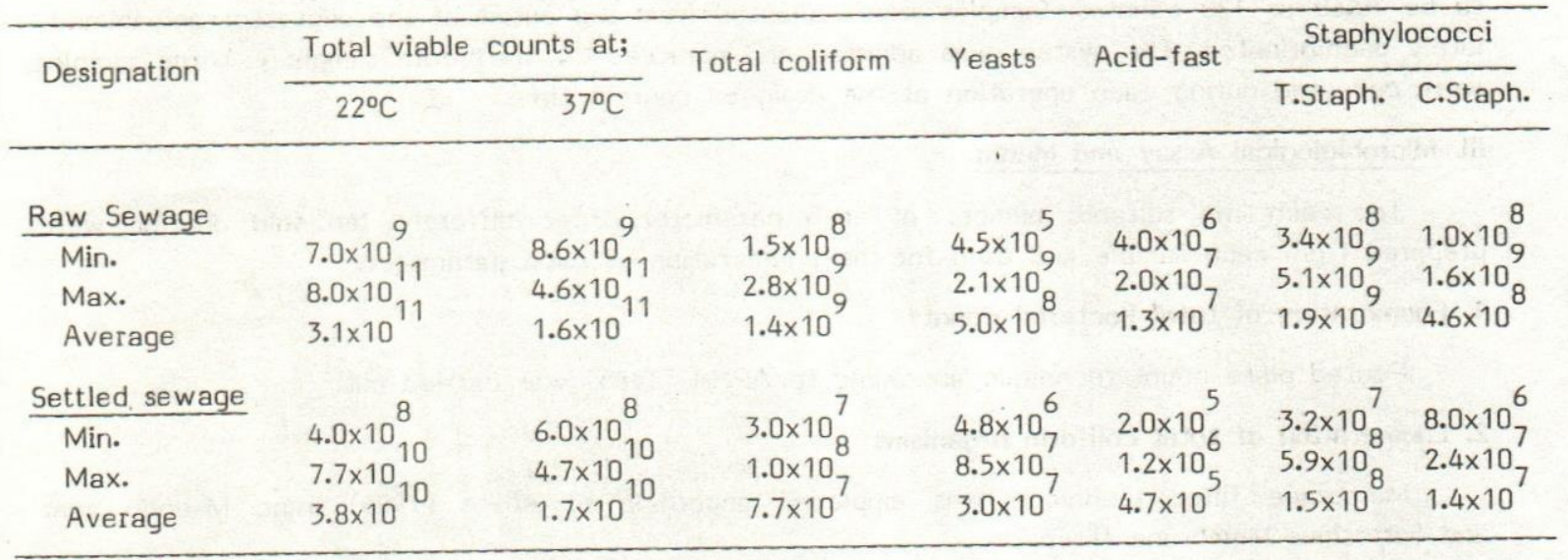

A high degree of reduction in total coliform density was observed in the biologically treated (RBCs) effluent. Further reduction was also observed after settling of the treated effluent. Yeast numbers was still showing the highest density as compared with the average density of the other bioindicators (Table 2). Generally, all tested bioindicators were detected in tested samples all over the year.

Assiut Vet.Med.J. Vol. 18, No. 35, 1987. 


\section{EL-HAWAARY and KHALAFALLA}

Table (2)

The density of bioindicators in Liolegically treated sewage and primary settled effluent

\begin{tabular}{|c|c|c|c|c|c|c|c|}
\hline \multirow{2}{*}{ Designation } & \multicolumn{2}{|c|}{ Total viable counts at: } & \multirow{2}{*}{ Total coliform } & \multirow{2}{*}{ Yeasts } & \multirow{2}{*}{ Acid-fast } & \multicolumn{2}{|c|}{ Staphylococci } \\
\hline & $22^{\circ} \mathrm{C}$ & $37^{\circ} \mathrm{C}$ & & & & T.Staph. & C.Staph. \\
\hline \multicolumn{8}{|l|}{ Raw effluent } \\
\hline Min. & $2.8 \times 10_{8}^{6}$ & $3.0 \times 10_{7}^{5}$ & $9.5 \times 10_{5}^{3}$ & $3.1 \times 10^{4}$ & $3.0 \times 10_{5}^{3}$ & $9.8 \times 10_{5}^{3}$ & $6.0 \times 10^{3}$ \\
\hline Max. & $1.1 \times 10_{7}^{8}$ & $9.0 \times 10_{7}^{7}$ & $2.3 \times 10^{5}$ & $4.2 \times 10_{5}^{6}$ & $1.6 \times 10^{5}$ & $9.1 \times 10_{5}^{5}$ & $3.4 \times 10^{4}$ \\
\hline Average & $8.5 \times 10^{7}$ & $6.2 \times 10^{7}$ & $5.7 \times 10^{4}$ & $7.4 \times 10^{5}$ & $8.4 \times 10^{4}$ & $1.8 \times 10^{5}$ & $1.7 \times 10^{4}$ \\
\hline \multicolumn{8}{|l|}{ Settled effluent } \\
\hline Min. & $1.5 \times 10_{7}^{6}$ & $1.2 \times 10_{7}^{6}$ & $1.0 \times 10^{3}$ & $5.5 \times 10_{4}^{3}$ & $1.7 \times 10_{4}^{4}$ & $3.6 \times 10_{4}^{4}$ & $3.6 \times 10^{3}$ \\
\hline Max. & $9.2 \times 10_{7}^{\prime}$ & $5.3 \times 10_{7}^{\prime}$ & $7.0 \times 10^{3}$ & $6.6 \times 10_{4}^{4}$ & $5.8 \times 10_{4}^{4}$ & $6.4 \times 10_{4}^{4}$ & $8.6 \times 10^{3}$ \\
\hline Average & $3.76 \times 10^{\prime}$ & $1.9 \times 10^{\prime}$ & $3.6 \times 10^{3}$ & $5,6 \times 10^{4}$ & $2.1 \times 10^{4}$ & $4.3 \times 10^{4}$ & $6.2 \times 10^{3}$ \\
\hline
\end{tabular}

To verify resistance of yeasts, (A-F), (TC) and (Staph.) organisms to chlorine inactivation, under the same conditions, batch experiments were performed in the laboratory at room temperature. The average numbers of three experiments are indicated in figure 1. As shown from this figure, acid fast organisms are consistantly showing the lowest inactivation rate. Total coliform organisms exhibited the highest rate of inactivation, except within a time of contact less than $15 \mathrm{~min}$. Coloured Staphylococci showed the lowest degree of tolerance to chlorine disinfection, up to $15 \mathrm{~min}$ contact time. While total staphylococci were equally persistant as total coliforms within the same period of inactivation (Fig. 1). However, total staphylococci presented moderate values of persistance between acid-fast and yeasts on one hand and coloured staphylococci and total coliforms on the other one especially after 15 min. of contact time.

Continuous flow chlorine inactivation experiments were performed to distinguish the resistance of the acid-fast and yeasts as well as coliform organismis and staphylococci under dynamic conditions, i.e., under conditions more closely resembling that of water and wastewater disinfection facilities. It is also permitted a direct comparison of the relative resistance of the different bioindicators to chlorine under the same simultaneous conditions. However comparison of these results with those of batch experiments showed a close agreement (Fig. 2). As shown in this figure, variation in persistance was also observed in all the tested parameters. One of the obviously noticed observations is the delay in chlorine disinfection. activity. This delay may be due to lack of homogenity especially at the enterance of buffled contactor.

\section{DISCUSSION}

The data in tables 1 \& 2 show the consistent presence of all the tested parametegrs in all 9 examined samples. Compared with total coliform density, which ranged between $10^{8}$ and $10^{9}$ with an average value of $1.4 \times 10^{9} / 100 \mathrm{ml}$, yeasts and acid-fast organisms were found at lower densities in raw wastewater.

Total coliform counts in raw sewage were consistently higher than that of yeasts or Acid fast indicators by an order of one and two logs respectively. It was also found that counts 


\section{RESISTANCE OF BIOINDICATORS TO CHLORINATION}

of staphylococci in most cases are closely intemate to that of total coliforms. The diversity in density was disappeared after the biological treatment. Further-more, after sedimentation of the treated effluent, the density of yeast was outnumbered as compared with that of total staphylococci and total coliform organisms, but still acid-fast and staphylococci having the same log counts.

The density of total coliform organisms reached $7 \times 10^{3} / 100 \mathrm{ml}$ as a maximum value with an average of $3.6 \times 10^{3}$ organisms per $100 \mathrm{ml}$. Organisms densities of yeasts, total staphylococci and acid-fast bacteria averaged $5.6 \times 10^{4}, 4.3 \times 10^{4}$ and $2.1 \times 10^{4}$ respectively. This means that total coliform organisms are susceptible to biological treatment than the other three tested parameters. The yeast and acid-fast densities appeared to be less variable than both staphylococci and total coliform organisms. This data are in agreement with that reported by GRABOW, et al. (1980) with two exceptions related to total coliform and total viable bacterial counts. While they reported an increase in total bacteria and total coliform counts after primary clarification reached $14.2 \%$ and $11 \%$, the present work reported a reduction reached $69 \%$ and $94 \%$ respectively. This could be due to differences in the treated influent, composition and the capacity and the type of treatment system.

From the results achieved, one can safely conclude that yeasts and acid-fast organisms are continually present during the one year in raw wastewater and treated effluents in a detectable levels and may, as a result, be used as an indicator organisms. ENGELBRECHT and COWORKERS (1977 \& 1979) reached the same conclusion and reported the presence of yeasts and acid-fast organisms in human feaces in average values of 562 \& 18.9 per gram of wet faeces, respectively.

As shown, it is clear from our results that yeast and acid-fast organisms exhibited a greater resistance to the action of chlorine under laboratory and continuous flow system than that of total coliform and pathogenic or coloured staphylococci or even total staphylococci.

These data clearly demonstrated the superior resistance of these two groups of organisms over that of the other two studied ones, i.e. total coliforms and staphylococci. So, the natural distribution or ecology as well as persistance in natural environment of yeasts and acid-fast organisms in addition to their enumeration facilities must be concerned in future.

\section{ACKNOWLEDGMENT}

The authors are greatly endebted to Prof. Dr. Fatma El-Gohary, head of Water Pollution Control Laboratory, NRC and Mr. M.H. Awady for their help in conducting this work.

\section{REFERENCES}

Aptia (1985): Standard Methods for Examination of Water and Wastewater. 15th ed., APHA, AWWA, AWPCF, Washington, D.C.

Berg, G. and Metcalf, T.G. (1978): Indicators of viruses in waters. In indicators of viruses in water and food. G.Berg (Ed). Arber Science Publ. Inc. Mitchigan (1978) pp. 267-296.

Bonde, G.J. (1966): Bacteriological methods for estimation of water pollution. Health Lab. Sci., 31: 124.

Assiut Vet.Med.J. Vol. 18, No. 35, 1987. 


\section{EL-HAWAARY and KHALAFALLA}

Difco Manual (1958): Of dehydrated culture media and reagents for microbiological and clinical laboratory procedures. 9th ed., U.S.A.

Engelbrecht R.S.; Severin, B.F.; Masarik, M.T.; Farooq, S.; Lee, S.H.; Haas, C.N. and Lalchandani, A. (1977): New microbial indicators of disinfection eficiency. Environmental Protection Technology Series, U.S. EPA-600/1-77-052.

Engelbrecht, R.S.; Haas, C.N.; Shular, J.A.; Dann, D.L. Ror, D., Lalchandani, A.; Severin, B.F. and Farooq, S. (1979): Acid-fast bacteria and yeasts as indicators of disinfection efficiency. U.S.EPA 600/2-79-091.

Gallagher, J.P. and Spino, D.F. (1968): The significance of coliform bacteria as an indicator of enteric pathogens. Water Res. 2: 169.

Geldreich, E.E.; Best, I.C.; Kenner, B.A. and Van Donsel, D.J. (1968): The bacteriological aspects of stormwater pollution. J.WPCF., 40: 1861.

Grabow, W.O.K.; Burger, T.S. and Nupen, E.M. (1980): Evaluation of acid-fast bacteria, Candida albicans, enteric viruses and conventional indicators for monitoring wastewater reclamation systems. Prog. Wat. Tech., 12: 803.

McFeters, G.A.; Bissonnette, G.K., Jezeski, J.J.; Thomson, C.A. and Stuart, D.G. (1974): Comparative survival of indicator bacteria and enteric pathogens in well water. Appl. Microbiol., 27: 823 .

Rudolphs, W.; Folk, 1.l. and Ragotzkie, R.A. (1950): Literature Review on the occurrence and survival of enteric pathogenic and relative organisms in soil, water, sewage and sludgs and on vegetation. I. Bacterial and viral diseases. Sewage Ind. Wastes, 22: 1261.

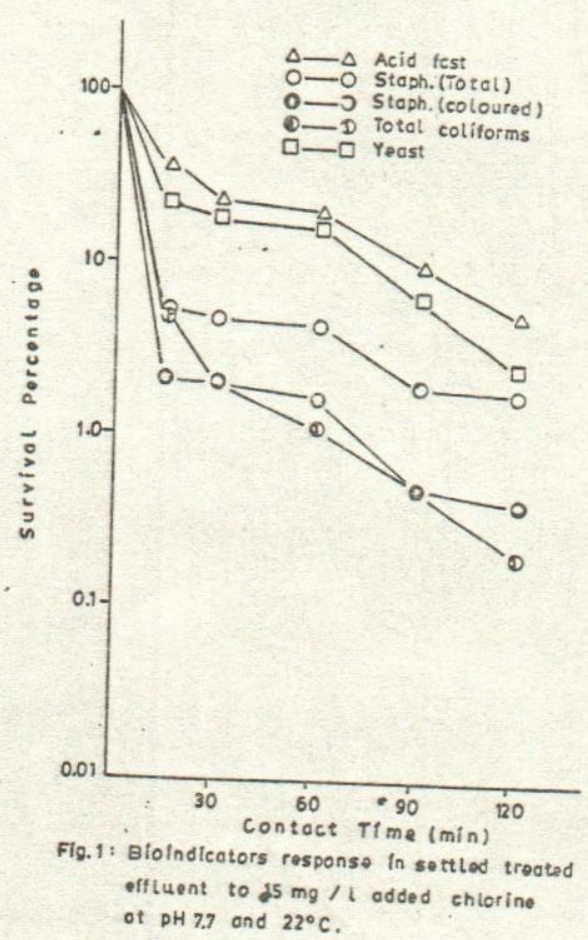

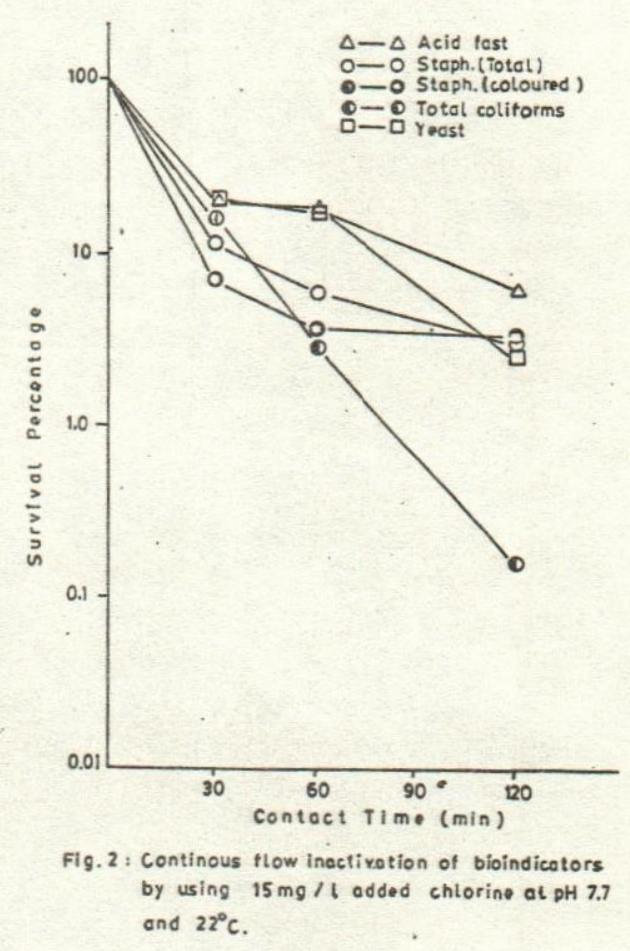

Assiut Vet.Med.J. Vol. 18, No 35, 1987. 